\title{
PENETAPAN KADAR TOTAL ARSENIK DALAM MAKANAN PENDAMPING AIR SUSU IBU DENGAN INSTRUMEN AAS-HVG: VERIFIKASI METODE DAN PERBANDINGAN PROGRAM MICROWAVE
}

\section{Determination of Total Arsenic in Complementary Food by HVG-AAS: Method Verification and Comparison of Microwave Program}

\author{
Suyanto ${ }^{1,2}$, Hanifah Nuryani Lioe $^{1 *}$, Puspo Edi Giriwono ${ }^{1,3}$, Dedi Fardiaz ${ }^{1,3}$ \\ ${ }^{1}$ Departemen Ilmu dan Teknologi Pangan - Fakultas Teknologi Pertanian - IPB \\ Kampus Darmaga - Bogor 16680 \\ ${ }^{2}$ Badan Pengawas Obat dan Makanan RI (Indonesian FDA) \\ Jalan Percetakan Negara No. 23 - Jakarta 10560 \\ 3South East Asian Food and Agricultural Science and Technology (SEAFAST) Center - IPB \\ Kampus Darmaga - Bogor 16680 \\ *Penulis Korespondensi, email: hanifahlioe@apps.ipb.ac.id
}

Disubmit : 08 April 2021

Direvisi : 20 Juli 2021

Diterima : 19 Agustus 2021

\begin{abstract}
ABSTRAK
Pemilihan program digesti sampel dengan microwave penting dilakukan untuk memperoleh hasil destruksi yang sempurna. Kesempurnaan destruksi sampel menentukan keberterimaan parameter verifikasi metode yaitu akurasi, presisi, linearitas dan sensitivitas. Penelitian ini bertujuan untuk memilih metode destruksi microwave dalam penetapan total arsenik dalam MP-ASI menggunakan AAS-HVG. Evaluasi dilakukan terhadap parameter verifikasi metode dan perbandingan dua program microwave dilakukan dengan uji t. Hasil penelitian menunjukkan bahwa program destruksi microwave pertama (P1) lebih baik daripada program microwave pembanding (P2) yang menghasilkan rata-rata recovery $84,79 \%$ hingga $104,57 \%$ untuk sampel bermatriks makanan dan $64,43 \%$ untuk sampel air. Presisi metode terpilih menghasilkan rata-rata RSD 6,63\% hingga 13,41\% untuk sampel bermatriks dan 4,66\% untuk sampel air. Linearitas metode pada program terpilih menunjukkan R:0,997 dengan koefisien variasi regresi $\mathrm{Vx} 0: 4,24 \%$, sedangkan batas deteksi dan batas kuantifikasi sebagai parameter sensitivitas berturut-turut $0,04 \mathrm{ng} / \mathrm{g}$ dan $0,12 \mathrm{ng} / \mathrm{g}$ untuk sampel bermatriks serta $0,01 \mathrm{ng} / \mathrm{ml}$ dan $0,02 \mathrm{ng} / \mathrm{ml}$ untuk sampel air. Metode penetapan kadar total arsenik dengan program microwave terpilih memenuhi syarat keberterimaan menurut uji verifikasi metode
\end{abstract}

Kata kunci: Arsenik; Digesti; Microwave; Makanan Pendamping Asi; Verifikasi Metode

\begin{abstract}
It is important to choose a sample digestion program with microwave to obtain the best digestion results. The sample digestion may determine the acceptability of the method verification parameters, namely accuracy, precision, linearity and sensitivity. The aim of this study was to select a microwave digestion method in determining the total arsenic in complementary foods using HVG-AAS. The evaluation was carried out on the parameter verification method and the comparison of the two microwave programs was carried out using the $t$ test. The results showed that the first microwave digestion program (P1) was better than the comparator microwave program (P2) which resulted in an average recovery of $84.79 \%$ to $104.57 \%$ for matrix samples and $64,43 \%$ for water samples. The precision of the selected method resulted in an average RSD of $6.63 \%$ to $13.41 \%$ for food matrix samples and $4.66 \%$ for water samples. The linearity of the method in the selected program shows R: 0.997 with a regression coefficient of variation $V x 0: 4.24 \%$, while the limit of detection and limit of quantification as
\end{abstract}


Jurnal Teknologi Pertanian Vol. 22 No. 2 [Agustus 2021] 129-138

Penetapan Kadar Total Arsenik dalam Makanan Pendamping Air Susu Ibu [Suyanto dkk]

sensitivity parameters are $0.04 \mathrm{ng} / \mathrm{g}$ and $0.12 \mathrm{ng} / \mathrm{g}$ for matrix samples respectively $0.01 \mathrm{ng} / \mathrm{ml}$ and 0.02 $\mathrm{ng} / \mathrm{ml}$ for water samples. The method for determining the total arsenic concentration using the selected microwave program met the acceptability requirements according to the method verification test.

Keywords : Arsenic, Digestion, Microwave, Complementary Food, Method Verification

\section{PENDAHULUAN}

Tahap analisis arsenik dalam sampel terdiri dari preparasi sampel hingga diperoleh larutan analitik dan penentuan arsenik dengan instrumen. Preparasi sampel harus dilakukan dengan baik, karena tahap ini merupakan salah satu tahapan kritis dalam keseluruhan rangkaian pengujian arsenik (Welna et al., 2015). Preparasi sampel bertujuan untuk meniadakan atau mengurangi gangguan saat pengukuran analit, minimalisasi kontaminasi, ketertelusuran hasil dengan melibatkan jumlah sampel, reagen, waktu dan limbah sekecil mungkin (de Oliveira, 2003). Sebagai contoh, perubahan aliran elektroosmotik dalam kapiler karena matriks sampel dapat menyebabkan gangguan dalam pengukuran analit. Gangguan dapat juga berasal dari sisa karbon yang tinggi karena digesti belum sempurna (Müller et al., 2014). Demikian juga baseline detektor dapat terganggu jika $\mathrm{pH}$ sampel berbeda dengan $\mathrm{pH}$ larutan blanko. Perlu dilakukan strategi untuk melakukan ekstraksi, pemekatan atau pra-konsentrasi, dan derivatisasi sampel sebelum pengukuran menggunakan instrumen (Gómez-Ariza et al., 2001).

Microwave dengan sistem vesel tertutup merupakan cara digesti sampel yang digunakan untuk analisis kuantitatif total As maupun spesies arsenik (Alava et al., 2012). Gelombang mikro sering digunakan untuk mengekstraksi matriks biologis dan lingkungan, jauh lebih cepat daripada prosedur ekstraksi Soxhlet. Parameter seperti daya gelombang mikro yang diterapkan dan waktu pemaparan atau suhu dan waktu pemaparan harus dioptimalkan untuk kesempurnaan hasil digesti (de Oliveira, 2003). Penggunaan microwave untuk ekstraksi sampel disertai dengan penggunaan pelarut asam encer atau pelarut organik dengan kombinasi suhu. Raber et al. (2012) melaporkan bahwa ekstraksi menggunakan gelombang microwave, dapat digunakan untuk penentuan arsenik dalam makanan. Digesti matriks sampel secara microwave menyebabkan unsur logam arsenik lepas dari matriks organiknya. Matriks organik terurai menjadi unsur-unsur karbon, hidrogen, dan oksigen. Matriks tersebut selanjutnya tidak mengganggu dalam pengukuran. Pada umumnya digesti microwave dilakukan dengan pelarut asam kuat dengan program microwave tertentu tergantung dari jenis matriks organiknya (de Oliveira, 2003).

Tujuan dari penggunaan microwave untuk memperoleh hasil digesti sempurna sehingga diperoleh larutan analit logam secara valid, dekomposisi matriks secara sempurna, terhindar dari hilangnya analit serta kontaminasi dan kemudahan penanganan termasuk penghematan waktu (de Oliveira, 2003). Pada digesti sampel organik digunakan pelarut asam, suhu dan tekanan microwave yang optimal yaitu berkisar $300{ }^{\circ} \mathrm{C}$ dan 200 bar (Müller et al., 2014). Asam nitrat pekat merupakan asam yang biasa digunakan untuk digesti pada banyak macam sampel. Gelombang microwave berinteraksi dengan nitrat, menghasilkan $\mathrm{HNO}_{3}$ panas yang merupakan agen oksidator kuat untuk men-digest sampel organik sehingga banyak analit logam menjadi larut setelah digesti selesai (Müller et al., 2014). Dekomposisi matriks organik menjadi senyawa anorganik, seperti $\mathrm{CO}_{2}, \mathrm{NO}$ dan $\mathrm{H}_{2} \mathrm{O}$. Makanan penamping air susu ibu (MP-ASI) merupakan sampel pangan bermatriks kompleks yang memerlukan program digesti microwave yang tepat agar diperoleh hasil digesti yang sempurna.

Pengembangan prosedur atau program digesti secara microwave merupakan langkah penting sebelum sampel dianalisis dengan instrumen atomic absorption spectrometer-hydride vapour generator (AAS-HVG). Beberapa parameter yang berhubungan dengan matriks sampel, jenis analit logam, dan teknik penetapan harus dipertimbangkan untuk memperoleh 
hasil yang reliabel serta keamanan selama dekomposisi. Reagen yang digunakan juga memiliki interaksi dengan analit, oleh karena itu reagen pun perlu dipilih yang tidak membentuk senyawa yang mudah menguap atau berikatan kuat dengan analit (Müller et al., 2014). Sampel pangan dan matriks biologi lainnya disusun oleh tiga kelompok utama yaitu karbohidrat, protein dan lemak. Oksidasi karbohidrat dengan asam nitrat pada umumnya lebih cepat daripada oksidasi protein dan lemak (Müller et al., 2014). Jumlah sampel pangan yang didigesti maksimum $5 \mathrm{~g}$ dengan asam nitrat pekat $8 \mathrm{ml}$ dan hidrogen peroksida $1 \mathrm{ml}$, secara microwave CEM dengan tekanan 50 bar pada suhu $200{ }^{\circ} \mathrm{C}$ (Müller et al., 2014), tetapi menurut de Oliveira (2003) berat sampel bisa sampai $10 \mathrm{~g}$. Secara umum berat sampel untuk digesti microwave sebesar 0,2 sampai $1 \mathrm{~g}$ dengan maksimum suhu 180 hingga $200{ }^{\circ} \mathrm{C}$ dan waktu kurang dari 30 menit. Tetapi bagaimanapun tetap tergantung dari sistem dan kondisi microwave, serta kandungan asam lemaknya (Würfels et al., 1989).

Verifikasi metoda analisis adalah suatu tindakan penilaian terhadap parameter tertentu, berdasarkan percobaan laboratorium, untuk membuktikan bahwa parameter tersebut memenuhi persyaratan sesuai penggunaannya (ISO/IEC 17025:2017, 2017). Parameter utama verifikasi metode meliputi kecermatan, keseksamaan, linearitas, dan batas deteksi. Kecermatan atau akurasi adalah ukuran derajat kedekatan hasil analis dengan kadar analit yang sebenarnya. Keseksamaan atau presisi adalah ukuran derajat kesesuaian antara hasil uji individual terhadap sebaran hasil individual yang diterapkan secara berulang. Keseksamaan diukur sebagai simpangan baku atau simpangan baku relatif. Ia dinyatakan juga sebagai keterulangan (repeatability/reproducibility). Keterulangan adalah keseksamaan metode jika dilakukan berulang kali oleh analis yang sama pada kondisi sama dan dalam interval waktu yang pendek. Linearitas merupakan rentang standar dengan jarak konsentrasi tertentu dengan respon yang membentuk garis lurus menurut titik-titik yang dibentuk. Linearitas, adalah kemampuan metode analisis yang memberikan respon secara langsung dan proporsional terhadap konsentrasi analit. Rentang metode adalah pernyataan batas terendah sampai batas tertinggi analit yang sudah ditunjukkan dapat ditetapkan dengan kecermatan, keseksamaan, dan linearitas yang dapat diterima. Batas deteksi dan kuantifikasi, adalah jumlah terkecil analit dalam sampel yang dapat dideteksi yang masih memberikan respon signifikan dibandingkan dengan blangko. Batas kuantitasi merupakan parameter diartikan sebagai kuantitas terkecil analit dalam sampel yang masih dapat memenuhi kriteria kecermatan dan keseksamaan (AOAC, 2016). Parameter tersebut merupakan titik kritis dalam penetapan kadar arsenik, oleh karena harus dilakukan dengan tepat (Welna et al., 2015).

Apabila sebuah laboratorium menggunakan metode standar yang telah dipublikasi, laboratorium yang bersangkutan harus memverifikasi, walaupun hanya pada aspek-aspek tertentu. Hal ini dimaksudkan agar laboratorium tersebut memiliki data objektif unjuk kerja dan memastikan bahwa metode sesuai penggunaannya, mengingat masing-masing laboratorium memiliki kondisi berbeda, serta akomodasi, lingkungan, kompetensi personil, dan kinerja peralatan yang berbeda (ISO/IEC 17025:2017, 2017). Aspek pengujian tersebut antara lain akurasi, presisi, linearitas, batas deteksi dan batas kuantitasi (AOAC, 2016).

Banyak tersedia program digesti secara microwave, pada umumnya tersedia dalam manual penggunaan alat dan juga pada jurnal penetapan kadar total arsenik. Program tersebut harus dipilih yang terbaik, disesuaikan dengan matriks sampel pangan yang diuji. Evaluasi program digesti perlu dilakukan dengan parameter uji verifikasi, dimaksudkan untuk mengetahui kinerja metode. Perbandingan program digesti microwave secara manual alat yang dilaporkan CEM dan yang dilakukan oleh Narukawa et al. (2014) diteliti dalam penelitian ini untuk mengetahui metode terbaik dengan kinerja metode yang diterima.

\section{METODE}

Alat yang digunakan pada penelitian antara lain alat gelas, hot plate (Molleb $\mathrm{KG}$ ), microwave digester MARS X-Press (CEM Corporation, USA), seperangkat alat 
AAS (Agilent AA280FS/VGA, USA) (Atomic Absorption Spectrophotometry) yang dilengkapi dengan unit HVG (Hydride Vapor Generator) (Agilent AA280FS/VGA, USA).

Bahan kimia yang digunakan adalah air ultra murni 18.2 M.cm dari Milli-Q® Merck (Jerman) untuk analisis, asam nitrat $(65 \%$ Suprapur ${ }^{\circledR}$ ), asam hidroklorida (fuming 37\% Emsure $\left.{ }^{\circledR}\right)$, hydrogen peroksida (30\% Emsure $\left.{ }^{\circledR}\right)$, sodium hidroksida (pellet Emsure ${ }^{\circledR}$ ), asam Laskorbat (Emsure $\left.{ }^{\circledR}\right)$, sodium borohidrida (pro analysis) dan potassium iodide (pro analysis Emsure ${ }^{\circledR}$ ), magnesium nitrat heksahidrat (pro analysis Emsure ${ }^{\circledR}$ ) dan stok larutan standar (SRM As V 1000 mg/l, Certipur tertelusur ke SRM NIST (dalam $\mathrm{HNO}_{3} 2-3 \%$ ). Semua bahan kimia berasal dari Merck KGaA (Darmstadt, Jerman).

Sampel uji menggunakan empat macam kelompok MP-ASI, yaitu bubur siap saji non-registrasi (SPL 01-K), makanan selingan siap saji (SPL 05-K), air minum galon isi ulang (SPL 17-KT), minuman lain bermatriks (SPL 20-K). Masing-masing sampel merupakan sampel komposit homogen yang berisi dari beberapa produk yang dikonsumsi anak. Sampel komposit dibuat dari serangkaian survei konsumsi yang tidak disampaikan dalam paper ini.

\section{Preparasi Sampel}

Preparasi sampel meliputi preparasi sampel makanan dan homogenisasinya, serta preparasi larutan analitik yang dimulai dari digesi sampel makanan dengan penamabahan asam kuat dan pemanasan dalam microwave oven hingga diperoleh larutan sampel analitik. Terhadap alat-alat gelas, vessel microwave dan wadah yang terlibat dilakukan pencucian dengan cara direndam menggunakan larutan asam nitrat $10 \%(\mathrm{v} / \mathrm{v})$ semalam, kemudian dibilas menggunakan air $18 \mathrm{M} \Omega \mathrm{cm}$ dan dikeringkan (AOAC, 2005).

Sampel yang dipreparasi berupa makanan pendamping ASI, yang diperoleh dengan cara mencampur secara proporsional sesuai jumlah yang dikonsumsi anak. Sampel komposit tersebut selanjutnya dihomogenisasi menggunakan blender sampai homogen (Otles dan Ozyurt, 2015). Sejumlah sampel homogen ditimbang secara saksama $\pm 0,2-2,5 \mathrm{~g}$ komposit sampel yang telah dihomogenisasi, dimasukkan ke dalam vessel PTFE diikuti oleh $5 \mathrm{ml} \mathrm{HNO} 3(65 \%)$ dan $1 \mathrm{ml} \mathrm{H} \mathrm{H}_{2} \mathrm{O}_{2}(30 \%)$
(AOAC, 2005). Sampel didestruksi dengan microwave oven dengan aplikasi program (2.1.1) yang diteliti, untuk 18 vessel. Sampel didinginkan dan kemudian ditara ke dalam labu tentukur volume $25 \mathrm{ml}$ dengan air ultra murni 18,2 M'cm. Alikuot larutan 10 $\mathrm{ml}$ dituangkan ke dalam krus porselen dan dicampur dengan $2 \mathrm{ml} \quad 7 \% \quad \mathrm{Mg}\left(\mathrm{NO}_{3}\right)_{2}$. Sampel kemudian diuapkan di atas hotplate hingga kering. Selanjutnya krus dipanaskan dalam muffle furnace dengan suhu $450 \quad{ }^{\circ} \mathrm{C}$ selama 1 jam. Setelah didinginkan hingga suhu kamar, dituangkan $2 \mathrm{ml} \mathrm{HCl} 6 \mathrm{M}$, diaduk dan larutan dipindahkan ke dalam labu ukur 10 $\mathrm{ml}$, krus dibilas dua kali, bilasan dituang ke labu yang sama dan kemudian ditara hingga volume akhir $10 \mathrm{ml}$ dengan air ultra murni. Alikuot 5,0 $\mathrm{ml}$ dari larutan ini kemudian dicampur dengan 5,6 ml larutan reduksi (30 mM KI; $28 \mathrm{mM} \mathrm{L-0,1 \%} \mathrm{asam}$ askorbat; dan $3 \mathrm{M} \mathrm{HCl}$ ) dan dibiarkan bereaksi selama 60 menit pada suhu kamar. Selanjutnya, 4,8 $\mathrm{ml} \mathrm{HCl} 3$ M ditambahkan dan dibiarkan bereaksi selama 60 menit lagi pada suhu kamar sebelum pengukuran AAS-HVG (Saxena et al., 2017).

\section{Program Microwave untuk Digesti Sampel}

Program microwave merupakan serangkaian program yang digunakan untuk mendigesti matriks sampel sampai siap diukur secara AAS-HVG. Program microwave berikut merupakan program yang akan dibandingkan untuk dipilih yang terbaik. Dua program yang dievaluasi adalah program microwave yang disediakan oleh manual alat MARS XPress CEM (program microwave pertama atau P1) dan program microwave yang dilakukan Narukawa et al. (2014) (program microwave pembanding atau P2).

\section{Program microwave pertama (P1)}

Program pertama (P1) adalah program dari manual alat MARS X-Press (CEM Corporation, USA) dengan program digesti untuk 18 vessel, yaitu First stage: Power $=800 \mathrm{~W}, 100 \%$; Ramp time $(\mathrm{min})=2$; $120{ }^{\circ} \mathrm{C}$, Hold Time $(\mathrm{min})=5 \mathrm{~min}$; Second stage: Power $=800 \mathrm{~W}, 100 \% ;$ Ramp time $(\min )=5,150^{\circ} \mathrm{C}$; Hold Time $(\mathrm{min})=10 \mathrm{~min}$; Third stage: Power $=800 \mathrm{~W}, 100 \%$; Ramp time $(\min )=5,200{ }^{\circ} \mathrm{C}$; Hold Time $(\mathrm{min})=30 \mathrm{~min}$. 


\section{Program microwave pembanding (P2)}

Program pembanding (P2) adalah program microwave yang dilakukan Narukawa et al. (2014), yaitu First stage:Power $=200 \mathrm{~W}$, 100\%; Hold Time $(\mathrm{min})=5 \mathrm{~min}$; Second stage: Power $=300 \mathrm{~W}, 100 \%$; Hold Time $(\mathrm{min})=5 \mathrm{~min}$; Third stage:Power $=500 \mathrm{~W}, 100 \%$; Hold Time $(\mathrm{min})=10 \mathrm{~min} ;$ Fourth stage:Power $=600$ $\mathrm{W}, 100 \%$; Hold Time $(\mathrm{min})=5 \mathrm{~min}$.

\section{Pembuatan Kurva Standar}

Pembuatan larutan intermediet $\mathrm{As}^{\mathrm{V}} 1,0$ $\mu \mathrm{g} / \mathrm{ml}$ dengan cara dipipet $1,0 \mathrm{ml}$ larutan standar arsenik $\left(\mathrm{H}_{3} \mathrm{AsO}_{4}\right) 1000 \mu \mathrm{g} / \mathrm{ml}$, selanjutnya dimasukkan ke dalam labu 100 $\mathrm{mL}$ dan ditepatkan sampai tanda menggunakan air $18 \mathrm{M} \Omega \mathrm{cm}$.

Pembuatan larutan intermediet $\mathrm{As}^{\mathrm{V}} 100$ $\mathrm{ng} / \mathrm{ml}$ dengan cara dipipet $10,0 \mathrm{ml}$ larutan intermediet $1,0 \mu \mathrm{g} / \mathrm{ml}$ dimasukkan ke labu $100 \mathrm{ml}$. Selanjutnya ditambahkan $10 \mathrm{ml}$ asam nitrat $0,15 \mathrm{~mol} / \mathrm{l}$ menggunakan pipet volum, diencerkan hingga tanda menggunakan air 18 $\mathrm{M} \Omega \mathrm{cm}$.

Pembuatan larutan standar kerja level 0,1; 0,$3 ; 0,6 ; 1,25 ; 2,5 ; 5 ; 10 \mathrm{ng} / \mathrm{ml}$ sebagai arsenik (Calle et al., 2017), berturut-turut dengan cara dipipet 50, 150, 300, 625, 1250, 2500, $5000 \mu \mathrm{l}$ dari larutan standar intermediet $\mathrm{As}^{\mathrm{V}} 100$ $\mathrm{ng} / \mathrm{ml}$, dimasukkan ke labu $50 \mathrm{ml}$. Selanjutnya ke dalam masing-masing labu ditambahkan 5,6 $\mathrm{ml}$ larutan reduksi (KI-asam askorbat-HCl) dan didiamkan 1 jam. Setelah itu, campuran ditambahkan 4,8 $\mathrm{ml} \mathrm{HCl} 3 \mathrm{M}$ dan didiamkan 1 jam, kemudian ditepatkan hingga $50 \mathrm{ml}$ menggunakan air $18 \mathrm{M} \Omega \mathrm{cm}$ (Saxena et al., 2017).

\section{Pengukuran t-As dengan Instrumen AAS-HVG}

Prosedur penetapan kadar arsen total (t-As) meliputi preparasi sampel dan pengukuran analit (Saxena et al., 2017). Larutan kerja hasil preparasi sampel selanjutnya ditetapkan kadar t-As-nya dengan kondisi AAS-HVG yaitu air flow: 13,5 1/min, acetylene flow: 2,10 1/min, wavelength: $193,7 \mathrm{~nm}$, dan slit width $0,5 \mathrm{R} \mathrm{nm}$. Gas pembawa digunakan argon dengan kualitas ultrahigh-purity (99,998\%). Gas bahan bakar digunakan acetylene kualitas high-purity $(99,5 \%)$ dan udara yang disaring dan diambil melalui kompresor. Reduksi arsenik valensi $\mathrm{V}$ dilakukan dengan sodium borohydride $(0,6 \%)$ dan sodium hidroksida $(0,5 \%)$ dalam suasana asam asam hidroklorida $6 \mathrm{M}$ (Nugraha et al., 2017).

\section{Verifikasi}

Verifikasi metode dilakukan terhadap beberapa matriks sampel yang mewakili komposit MP-ASI. Beberapa komposit MP-ASI yang dijadikan wakil uji verifikasi metode adalah bubur siap saji non registrasi (01-K), makanan selingan siap saji (05-K), air minum isi ulang (17-KT) dan minuman lain bermatriks (20-K).

\section{Akurasi}

Cara penetapan akurasi, pada sampel uji dilakukan spike $50 \mathrm{ng} / \mathrm{g}$ arsenik (Saxena et al., 2017). Pada sampel 0,5 g spike dilakukan dengan cara dipipet $250 \mu 1$ larutan baku intermediet $100 \mathrm{ng} / \mathrm{ml}$ dimasukkan secara saksama pada sampel yang telah ditimbang dalam vessel microwave. Akurasi dengan larutan spike dilakukan sebanyak 8 kali. Setelah dilakukan pengukuran dan perhitungan, selanjutnya dihitung persen perolehan kembali. Berdasarkan besarnya spike, dihitung keberterimaan perolehan kembali (\% rekoveri) dengan rumus pada Persamaan (1).

Rekoveri

$(\% R)=\frac{(A-B)}{C} \cdot 100 \%$

Dimana $\quad \mathrm{A}=$ kadar analit yang diperoleh dari sampel yang dispike, $\mathrm{B}=$ kadar analit dalam sampel, $\quad C=$ kadar analit yang ditambahkan (spike). Keberterimaan akurasi dengan mengacu AOAC (2016) Appendix F: SMPR.

Presisi

Cara penetapan presisi, yakni dari sampel spike yang dilakukan sebanyak 8 kali. Setelah sampel diukur dan dihitung kadar analitnya selanjutnya ditentukan ripitabilitasnya dengan mencari \% RSD.

Besaran nilai presisi dihitung dengan mencari \% RSD, dengan rumus pada Persamaan (2).

$\operatorname{RSD}(\%)=\frac{S D}{x} \cdot 100$ 
Dimana $\mathrm{x}=$ nilai rata-rata. Keberterimaan presisi hasil hitung RSD dibandingkan dengan $\mathrm{CV}_{\text {Horwitz; }} \% \mathrm{RSD} \leq 2 / 3$ $\mathrm{CV}_{\text {Horwitz }}$ atau $0,66 \times \mathrm{CV}_{\text {Horwitz. Rumus }}$ $\mathrm{CV}_{\text {Horwitz }}(\%)=2^{1-0,5} \log \mathrm{C}$. Log $\mathrm{C}$ adalah logaritma konsentrasi analit (dalam bentuk fraksi). Keberterimaan parameter presisi mengacu ke AOAC (2016) Appendix F: SMPR.

\section{Linearitas}

Penetapan linearitas dilakukan untuk melihat tingkat linieritas metode pada daerah linier yang disesuaikan dengan rentang tujuan pengamatan berdasarkan persyaratan kadar analit dalam sampel. Pada uji linearitas digunakan seri larutan yang berbeda konsentrasinya dengan kadar analit dalam sampel 25, 50, 75, 100, 125, dan 150\% kadar arsenik dalam sampel (Harmita, 2004).

Berdasarkan kurva regresi yang dibentuk selanjutnya ditentukan besaran nilai koefisien variansi regresi linier $(\mathrm{Vx} 0)$ dan dibandingkan dengan angka keberterimaannya. Keberterimaan linearitas, ditetapkan dengan langkah menghitung harga b (slope); a (intercept) dan $\mathrm{r}$ (koefisien korelasi), selanjutnya diterima atau compliance jika $\mathrm{r} \geq 0,99 \quad$ (cemaran/residu) dan $\mathrm{Vx0} \leq$ $5 \%$. Nilai koefisien variansi regresi linier (Vx0) dihitung berdasarkan simpangan baku residu (Sy/x) dengan rumus pada Persamaan (3) dan (4).

$$
\begin{aligned}
& \frac{S y}{x}=\sqrt{\frac{\sum\left(Y_{i}-Y_{c}\right)^{2}}{n-2}} \ldots \ldots \ldots \\
& V x 0=\frac{S y / x}{b \cdot x_{\text {rata-rata }}} \cdot 100 \%
\end{aligned}
$$

Dimana, $\mathrm{b}=$ slope; $\mathrm{X}_{\text {rata-rata }}=$ kadar analit standar rata-rata dalam larutan baku seri; $\mathrm{n}=$ jumlah titik seri.

\section{Sensitifitas}

Sensitifitas ditetapkan berdasarkan Batas deteksi atau LOD (Limit of Detection) dan Batas kuantitasi atau LOQ (Limit of Quantification) yang dilaporkan dengan satuan yang sama dengan satuan kadar analit dalam sampel yang tercantum dalam persyaratan (standar). Sensitifitas dapat dicari berdasar standar deviasi residual kurva baku (Sy/x) ataupun berdasar blanko. Batas deteksi $=3(\mathrm{Sy} / \mathrm{x}) /$ slope atau dapat juga batas deteksi $(\mathrm{LOD})=$ nilai rata-rata blangko + 3SD, dan batas kuantisasi (LOQ) $=$ Nilai rata-rata blangko +10 SD. Perhitungan parameter batas deteksi dengan melakukan pengulangan minimal 6 kali menggunakan matrik blangko. Jika matrik blanko tidak memberikan respon, dilakukan spike dengan analit sekecil mungkin, mengacu pada AOAC (2019) Appendix K.

\section{Pengolahan Data}

Data diolah menggunakan Software Microsoft Excel. Kadar arsenik dihitung dengan berdasarkan kurva kalibrasi. Konsentrasi arsenik dalam sampel dihitung menggunakan rumus pada Persamaan (5).

$$
C(n g / g)=\frac{((Y-a-b l k) / b) \cdot V \cdot F p}{W}
$$

Dimana, C adalah konsentrasi arsenik dalam sampel (ng/g). Y dan blk adalah absorbans sampel dan blanko hasil pembacaan alat AAS, sedangkan a, b, V, Fp dan $\mathrm{W}$ berturut-turut adalah intercept, slope, volume sampel uji (ml), faktor pengenceran dan bobot sampel uji (g).

Uji perbandingan dua program digesti microwave dilakukan terhadap parameter verifikasi. Uji $\mathrm{t}$ dua ekor $(\alpha=$ $0,05)$ dilakukan terhadap dua perlakuan tersebut untuk mengetahui ada tidaknya perbedaan.

\section{HASIL DAN PEMBAHASAN}

\section{Perbandingan Dua Program Digesti Microwave}

Kurva baku kalibrasi merupakan dasar penetapan kadar total arsenik. Kurva kalibrasi yang diperoleh dari hasil pengukuran disajikan pada Gambar 1, Gambar 2 dan Tabel 1. Kurva tersebut memiliki slope 0,0368 dan 0,0348 masingmasing untuk sampel bermatriks dan sampel air. Atribut lain untuk intercept dan koefisien korelasi adalah -0,00142 dan 0,999 pada sampel bermatriks yaitu bubur siap 
saji non-registrasi (01-K) dan pangan selingan siap saji (05-K) dan minuman lain bermatriks (20-K), serta -0,00123 dan 0,995 untuk sampel air (17-KT). Parameter tersebut memenuhi syarat linearitas yaitu 0,99 .

Tabel 1. Slope, intercept dan koefisien korelasi kurva baku kerja yang digunakan penetapan kadar total As (t-As) dengan AAS-HVG dalam beberapa matriks makanan pendamping ASI (MP-ASI)

\begin{tabular}{cccc}
\hline $\begin{array}{c}\text { Matriks } \\
\text { Sampel }\end{array}$ & Slope & Intercept & $\mathbf{R}^{\mathbf{2}}$ \\
\hline SPL 01-K & 0,04 & $-0,001$ & 0,99 \\
SPL 05-K & 0,04 & $-0,001$ & 0,99 \\
SPL 17-KT & 0,04 & $-0,001$ & 0,99 \\
SPL 20-K & 0,04 & $-0,001$ & 0,99 \\
\hline
\end{tabular}

Keterangan: SPL 01-K: bubur siap saji non-registrasi, SPL 05-K: makanan selingan siap saji, SPL 17-KT: air minum galon isi ulang, SPL 20-K: minuman lain

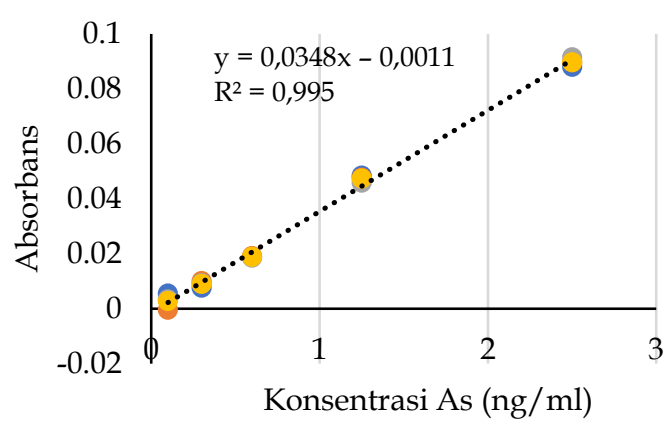

○ $2 \bigcirc 3 \bigcirc$ Mean

Gambar 1. Kurva baku kerja penetapan kadar total arsenik dalam matriks air. Pengukuran dilakukan sebanyak tiga ulangan

Program digesti microwave dirancang berdasarkan jenis kandungan matriks sampel pangan. Sampel yang mengandung lemak atau minyak lebih sulit terurai daripada protein dan protein lebih sulit terurai daripada selulosa atau karbohidrat. Kebutuhan energi microwave sebanding dengan tingkat kemudahan pemutusan rantai karbon. Program microwave yang optimal menentukan keteruraian matriks sampel yang lebih sempurna.

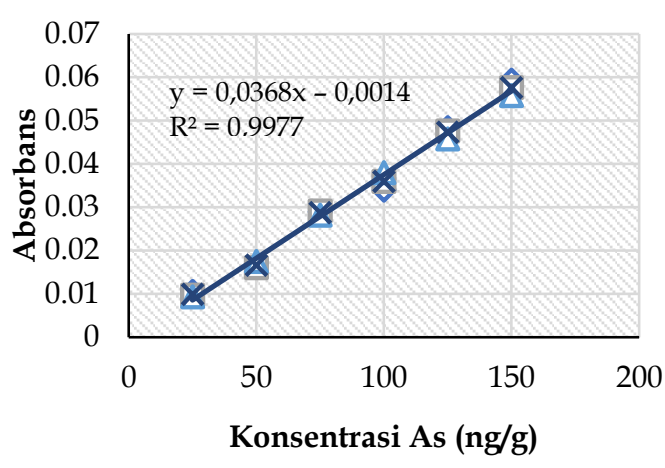

Gambar 2. Linearitas metode pada rentang konsentrasi t-As 25-150 ng/g dalam matriks komposit makanan MP-ASI, dengan atribut kurva slope $b=0,0368$, intercept $\mathrm{a}=-0,00108$, koefisien korelasi $\mathrm{R}=$ 0.997 dan koefisien variasi garis regresi $\mathrm{Vx} 0$ $=4,24 \%$. Pengukuran dilakukan sebanyak tiga ulangan

Evaluasi program microwave dilakukan terhadap hasil perhitungan akurasi dan presisi metode penetapan kadar. Hasil perhitungan parameter akurasi dan presisi disajikan pada Tabel 2 dan Tabel 3. Rata-rata akurasi sampel bermatriks $84,79 \%$ hingga $104,57 \%$ pada program microwave pertama dan $78,31 \%$ hingga $90,54 \%$ pada program microwave pembanding. Pada sampel air, mean akurasi $64,43 \%$ pada program microwave pertama dan $61,78 \%$ pada program microwave pembanding. Ketidakpastian pengukuran diperluas sebesar 0,27 hingga 0,30. 
Semua rata-rata dan rentang akurasi pada program pertama dan pembanding sesuai dengan syarat keberterimaan verifikasi (60-115\%) (AOAC, 2016). Program pertama maupun pembanding dapat digunakan sebagai program digesti, tetapi berdasarkan Uji t, kedua program berbeda secara siginifikan terhadap akurasi yang dihasilkan. Rata-rata akurasi program pertama berbeda secara nyata dengan program kedua, sehingga program pertama dapat dipilih sebagai program microwave dalam penetapan kadar total arsenik.

Presisi metode disajikan sebagai $\%$ RSD. Hasil perhitungan presisi verifikasi metode disajikan pada Tabel 3. Persentase RSD sampel bermatriks pada program pertama berkisar $6,63 \%$ hingga $13,41 \%$ dan pada sampel air $4,66 \%$. Pada program pembanding \%RSD lebih besar daripada program pertama yaitu $6,55 \%$ hingga $14,81 \%$ pada sampel bermatriks dan $4,28 \%$ pada sampel air. Semua rata-rata \%RSD pada program pertama dan pembanding memenuhi syarat keberterimaan verifikasi karena kurang dari 2/3 CV Horwitz. Kedua program digesti bisa digunakan dalam digesti sampel. Secara keseluruhan \%RSD program pertama lebih kecil daripada program kedua, dan hal ini berbeda nyata secara uji statistik, sehingga program pertama dapat dijadikan sebagai metode digesti terpilih.

Tabel 2. Rata-rata rentang rekoveri pada dua perlakuan penetapan kadar $t$-As dengan AASHVG pada beberapa kelompok komposit MP-ASI sebagai parameter akurasi

\begin{tabular}{cccccc}
\hline $\begin{array}{c}\text { Matriks } \\
\text { Sampel }\end{array}$ & $\mathbf{N}$ & $\begin{array}{c}\text { Program Pertama } \\
\mathbf{( P 1 )}\end{array}$ & $\begin{array}{c}\text { Program } \\
\text { Pembanding (P2) }\end{array}$ & $\begin{array}{c}\text { Ketidak } \\
\text { pastian } \\
\text { Uk }\end{array}$ & $\begin{array}{c}\text { Keberterimaan } \\
\text { rekoveri (\%) }\end{array}$ \\
\cline { 3 - 4 } SPL 01-K & 8 & $84,79^{\mathrm{a}}(71.47-98.84)$ & $82,59^{\mathrm{b}}(64,70-103,12)$ & 3,92 & $60-115$ \\
SPL 05-K & 8 & $104,57^{\mathrm{a}}(92,13-113,66)$ & $90,54^{\mathrm{b}}(76,48-115,66)$ & 3,92 & $60-115$ \\
SPL 17-KT & 8 & $64,43^{\mathrm{a}}(58,76-68,22)$ & $61,78^{\mathrm{b}}(59,70-68,00)$ & 3,92 & $60-115$ \\
SPL 20-K & 7 & $89,61^{\mathrm{a}}(79,29-99,86)$ & $78,31^{\mathrm{b}}(68,45-96,13)$ & 3,92 & $60-115$ \\
\hline
\end{tabular}

Keterangan : angka yang diikuti huruf sama dalam baris yang sama tidak berbeda nyata dalam Uji-t $5 \%$

Tabel 3. Rata-rata RSD dua perlakuan microwave program pada penetapan kadar $\mathrm{t}$-As dengan AAS-HVG pada beberapa kelompok komposit MP-ASI sebagai parameter presisi

\begin{tabular}{llcc}
\hline \multirow{2}{*}{$\begin{array}{c}\text { Matriks } \\
\text { Sampel }\end{array}$} & N & \multicolumn{2}{c}{ Rata-rata RSD (\%) } \\
\cline { 3 - 4 } & & $\begin{array}{c}\text { Program Pertama } \\
\mathbf{( P 1 )}\end{array}$ & $\begin{array}{c}\text { Program Pembanding } \\
(\text { P2) }\end{array}$ \\
\hline SPL 01-K & 8 & $8,15^{\mathrm{a}}(15,24)$ & $9,90^{\mathrm{b}}(15,31)$ \\
SPL 05-K & 8 & $6,63^{\mathrm{a}}(15,32)$ & $6,55^{\mathrm{b}}(15,53)$ \\
SPL 17-KT & 8 & $4,66^{\mathrm{a}}(20,90)$ & $4,28^{\mathrm{b}}(21,01)$ \\
SPL 20-K & 7 & $13,41^{\mathrm{a}}(18,88)$ & $14,81^{\mathrm{b}}(19,04)$ \\
\hline
\end{tabular}

Keterangan : angka yang diikuti huruf sama dalam baris yang sama tidak berbeda nyata dalam Uji-t ( $\mathrm{a}=$ 0,05). Angka dalam kurung adalah 0,66 RSD Horwitz

\section{Hasil Verifikasi Metode Terpilih}

Akurasi dilihat dari persentase rekoveri yang didapatkan. Rekoveri merupakan perolehan kembali analit arsenik yang ditambahkan ke dalam matriks. Berdasarkan dua program microwave yang digunakan, rekoveri keduanya terpenuhi (Tabel 2), tetapi secara signifikan program pertama memberikan rekoveri yang lebih baik, oleh karena itu program digesti ini yang dipilih untuk penetapan kadar total arsenik. Sampel bermatriks diwakili oleh bubur siap saji non-registrasi $(01-\mathrm{K})$, pangan selingan siap saji $(05-\mathrm{K})$ dan minuman lain bermatriks $(20-\mathrm{K})$, secara berturut-turut menunjukkan 
rata-rata rekoveri $84,79 \%$; $104,57 \%$, dan $89,61 \%$. Rekoveri analit rata-rata (rentang) pada sampel air minum (17-KT) sebesar $64,43 \%$ (58,76-68,22\%). Rentang rekoveri yang diperoleh pada semua sampel memenuhi syarat keberterimaan sebagaimana disebutkan diatas menurut AOAC (2016).

Presisi metode disajikan sebagai $\%$ RSD atau ripitabilitas atau kesaksamaan. Presisi metode pada program digesti yang terpilih disajikan pada Tabel 3. Tabel teresebut menunjukkan bahwa program pertama menunjukkan kesaksamaan yang lebih baik daripada program pembanding pada semua sampel uji. Pada sampel bubur siap saji non-registrasi, sampel pangan selingan siap saji dan minuman lain bermatriks menunjukkan \%RSD berturutturut $8,15 \% ; 6,63 \%$, dan $13,41 \%$, sedangkan pada sampel air minum isi ulang 4,66\%, semua nilai RSD memenuhi syarat keberterimaan, karena kurang dari $2 / 3 \mathrm{CV}$ Horwitz (AOAC, 2016).

Linearitas metode dalam verifikasi ini disajikan pada Gambar 2. Linearitas metode pada rentang konsentrasi t-As 25$150 \mathrm{ng} / \mathrm{g}$ dalam matriks komposit MP-ASI, mewakili $25-150 \%$ analit dalam sampel. Atribut kurva ditunjukkan dengan besaran slope $\mathrm{b}=0,000386$, intercept $\mathrm{a}=-0,00108$, koefisien korelasi $\mathrm{R}=0.997$ dan koefisien variasi garis regresi $\mathrm{Vx} 0=4,24 \%$. Syarat keberterimaan $\mathrm{R}$ untuk analit cemaran sebesar 0,99 dan syarat $\mathrm{Vx} 0$ sebesar $<5 \%$, oleh karena itu metode yang dipakai disimpulkan linear (Harmita, 2004).

Sensitivitas metode menggambarkan kepekaan metode ini dalam menetapkan kadar total arsenik. Semakin kecil sensitivitas metode semakin baik. Sensitivitas diekspresikan sebagai batas deteksi dan batas kuantifikasi. Pada sampel bermatriks batas deteksi dan batas kuantifikasinya sebesar 0,04 ng/g dan 0,12 $\mathrm{ng} / \mathrm{g}$, sedangkan untuk sampel air 0,01 $\mathrm{ng} / \mathrm{ml}$ dan $0,02 \mathrm{ng} / \mathrm{ml}$. Batas deteksi ini lebih kecil dari peneliti sebelumnya 0,069 $\mathrm{ng} / \mathrm{ml}$ dan 0,21 ng/ml (Komorowicz dan Barałkiewicz, 2016).

\section{SIMPULAN}

Verifikasi metode dilakukan sebagai upaya penjaminan bahwa metode penetapan kadar total arsenik memenuhi syarat sesuai penggunaannya. Berdasarkan hasil pengujian verifikasi, program pertama digesti microwave (P1) dapat dipilih sebagai metode digesti dalam penetapan kadar total arsenik. Secara keseluruhan berdasarkan hasil verifikasi, metode terpilih (P1) dapat digunakan untuk penetapan kadar total arsenik dalam MPASI.

\section{UCAPAN TERIMA KASIH}

Ucapan terima kasih disampaikan kepada Badan Pengawas Obat dan Makanan Republik Indonesia yang telah memberikan beasiswa studi S3 dan biaya riset kepada sdr. Suyanto.

\section{DAFTAR PUSTAKA}

Alava, -P., Van de Wiele, -T., Tack, -F., Du Laing, -G., 2012. Extensive grinding and pressurized extraction with water are key points for effective and species preserving extraction of arsenic from rice. Analytical Methods. 4, 1237-1243. https://doi.org/10.1039/c2ay25094b

AOAC, 2019. Appendix K: Guideline for Dietary Supplements and Botanical

AOAC, 2016. Appendix F: Guidelines for Standard Method Performance Requirements

AOAC, 2005. AOAC Official Method 999.10 Lead, Cadmium, Zinc, Cooper, and Iron in Foods

de Oliveira, -E., 2003. Sample preparation for atomic spectroscopy: Evolution and future trends. Journal of the Brazilian Chemical Society. 14, 174-182. https://doi.org/10.1590/S010350532003000200004 
Gómez-Ariza, A, -L., Morales, -E., Giráldez, -I., Sánchez-Rodas, -D., Velasco, A., 2001. Sample treatment in chromatography-based speciation of organometallic pollutants. Journal of Chromatography A. 938, 211-224. https://doi.org/10.1016/S00219673(01)01103-7

Harmita, 2004. Petunjuk pelaksanaan validasi metode dan cara perhitungannya. Majalah Ilmu Kefarmasian. 1, 117-135. http://dx.doi.org/10.7454/psr.v1i3.3375

ISO/IEC 17025:2017, 2017. General requirements for the competence of testing and calibration laboratories

Komorowicz, -I., Barałkiewicz, -D., 2016. Determination of total arsenic and arsenic species in drinking water, surface water, wastewater, and snow from Wielkopolska, KujawyPomerania, and Lower Silesia provinces, Poland. Environmental Monitoring and Assessment. 188, 504. https://doi.org/10.1007/s10661016-5477-y

Müller, EI, Mesko, MF, Moraes, DP, Korn, M. das GA, Flores, ÉMM. 2014. 'Wet Digestion Using Microwave Heating'. Dalam EMM Flores (Ed.). Microwave-Assisted Sample Preparation for Trace Element Determination. Elsevier, USA

Narukawa, -T., Suzuki, -T., Inagaki, -K., Hioki, -A., 2014. Extraction techniques for arsenic species in rice flour and their speciation by HPLC-ICP-MS. Talanta 130, 213-220. https://doi.org/10.1016/j.talanta.2014. 07.001

Nugraha, W, -C., Elishian, -C., Ketrin, -R., 2017. Determination of total arsenic in fish by hydride-generation atomic absorption spectrometry: Method validation, traceability and uncertainty evaluation. IOP Conference Series: Earth and
Environmental Science. 60, 012036. https://doi.org/10.1088/17551315/60/1/012036

Otles, S, Ozyurt, VH. 2015. Sampling and Sample Preparation, Handbook of Food Chemistry. Springer, New York

Raber, -G., Stock, -N., Hanel, -P., Murko, M., Navratilova, -J., Francesconi, K, -A., 2012. An improved HPLCICPMS method for determining inorganic arsenic in food: Application to rice, wheat and tuna fish. Food Chemistry. 134, 524-532. https://doi.org/10.1016/j.foodche m.2012.02.113

Saxena, S, -K., Karipalli, A, -R., Krishnan, A, -A., Rangasamy, -R., Malekadi, -P., Singh, D, -P., Vasu, -V., Singh, V, K., 2017. Determination and uncertainty analysis of inorganic arsenic in husked rice by solid phase extraction and atomic absorption spectrometry with hydride generation. Journal of AOAC International. 100, 598-602. https://doi.org/10.5740/jaoacint.1 7-0055

Welna, -M., Szymczycha-Madeja, -A., Pohl, -P., 2015. Comparison of strategies for sample preparation prior to spectrometric measurements for determination and speciation of arsenic in rice. TrAC Trends in Analytical Chemistry. 65, 122-136. https://doi.org/10.1016/j.trac.2014 .11 .007

Würfels, -M., Jackwerth, -E., Stoeppler, -M., 1989. Residues from biological materials after pressure decomposition with nitric acid: Part 1. Carbon conversion during sample decomposition. Analytica Chimica Acta. 226, 1-16. https://doi.org/10.1016/S00032670(00)80900-9 